\title{
Mapping of Sharia Cooperative Management Issue in Islamic Boarding Schools
}

\author{
Marlya Fatira AK \\ Politeknik Negeri Medan, Indonesia \\ email: marlyafatira@polmed.ac.id
}

\begin{abstract}
This study aimed to identify and analyze the issue faced by Islamic boarding schools (Kepontren) in Medan. This research method is Participatory Learning and Action (PLA), data collection through interviews, direct observation, and documentation. The research location is in the city of Medan. The data in this study are primary. The results showed that the issue faced by the Kepontren in Medan City consisted of an internal issue and an external issue. Mapping the condition of the Medan City Islamic Boarding School Cooperatives shows that eight cooperatives. However, only three active participants (37.5\%) are good enough and prosperous enough for their members; $62.5 \%$ are not developing, tend to be minor, and only sell the needs of the pesantren students. The implication of this research is to improve cooperative management in the pesantren environment in the city of Medan, especially in asset management, innovation, and strategy in human resource development. The novelty of this research is the application of Participatory Learning and Action from all environmental elements involved in the Pondok Pesantren cooperative.
\end{abstract}

Keywords: Potential Economic; Islamic Finance; Cooperatives; Islamic Boarding Schools

\begin{abstract}
Abstrak: Penelitian ini bertujuan untuk mengidentifikasi dan menganalisis permasalahan yang dihadapi oleh Pondok Pesantren (Kepontren) di Medan. Metode penelitian ini adalah Participatory Learning and Action (PLA), pengumpulan data melalui wawancara, observasi langsung, dan dokumentasi. Lokasi penelitian berada di kota Medan. Data dalam penelitian ini bersifat primer. Hasil penelitian menunjukkan bahwa permasalahan yang dihadapi oleh Kepontren di Kota Medan terdiri dari permasalahan internal dan permasalahan eksternal. Pemetaan kondisi Koperasi Pondok Pesantren Kota Medan menunjukkan bahwa terdapat delapan koperasi. Namun, hanya tiga peserta aktif $(37,5 \%)$ yang cukup baik dan cukup sejahtera bagi anggotanya; $62,5 \%$ tidak berkembang, cenderung kecil, dan hanya menjual kebutuhan santri pesantren. Implikasi dari penelitian ini adalah untuk meningkatkan manajemen koperasi di lingkungan pesantren di kota Medan khususnya dalam pengelolaan aset, inovasi, dan strategi dalam pengembangan sumber daya manusia. Kebaruan dari penelitian ini adalah penerapan Participatory Learning and Action dari seluruh elemen lingkungan yang terlibat dalam koperasi Pondok Pesantren.
\end{abstract}

Kata Kunci: Koperasi; Pesantren; Keuangan Syariah; Potensi Ekonomi

Economica: Jurnal Ekonomi Islam - Volume 11, Nomor 2 (2020) 


\section{Introduction}

Cooperative is not a new term for Indonesia; it is very well known; it is very integrated with the character of Indonesia. Cooperatives as financial institutions that exist, grow, and develop together with the essence of the Indonesian nation are generous, helpful, cooperative, and easy to help each other. This concept of mutual assistance in Islam is known as taawaun (helping each other) (A. L. R. Fikri, Yasin, and Jupri 2018). The concept of taawaun in financial management is known in activities in cooperatives.

Cooperatives for the Indonesian people are a people's economic forum that has the value of an instrument of economic cooperation and is clearly stated in the 1945 Constitution in Article 33, which states that "The Economy Is Structured As A Joint Effort On The Principle Of Kinship." This definition means that the economy in Indonesia is structured and implemented by prioritizing cooperation, mutual assistance, and mutual assistance to achieve mutual prosperity in a family environment as the Indonesian nation.

In its development, the existence of cooperatives grew together with other non-bank financial institutions in Indonesia, where Indonesia adheres to a dual banking system, namely conventional and sharia systems. Cooperatives with a sharia system are known as Islamic financial institutions. As a non-bank Islamic financial institution and other Islamic finance industries, Cooperatives are 28 years old. In its development, this Islamic financial services cooperative is also known as Baitul Maal wa Tamwil (BMT) (Wasiaturrahma et al. 2020)

Cooperatives in Indonesia have an essential role as economic actors who are considered to improve people's welfare. According to Lange (2010), in Indonesia, there are only three economic actors who are considered capable of improving people's interest, namely: State-Owned Enterprises (BUMN), Private-Owned Enterprises (BUMS), and Cooperatives. However, in its 
development, the three business entities still face many internal and external issues.

Cooperatives have become a mainstay in supporting the Indonesian economy, primarily through rural areas, by taking sides with the community's economy through its members by prioritizing kinship. This provision is regulated in article 33 of the 1945 Constitution and Article 4 of Law no. 25/1992 (Soemitra 2017).

In carrying out its operational activities, this cooperative is divided into cooperatives with conventional operations and cooperatives with sharia operations. Cooperatives with sharia operations will run their business by referring to all provisions regulated by Islamic sharia, based on the Koran, Al hadith, Ijtihad Ulama, and the Fatwa of the MUI DSN. This condition makes all members receive the overall sharia cooperative with good management according to Islamic Shia. However, it turned out not to be the case. Therefore, in its development, sharia cooperatives face a various issues, both in terms of legitimacy and formal legal basis; their practical activities face operational issues related to the application of sharia principles as useful references (Sholihin 2017).

Currently, sharia cooperatives are present in various community activities (Sakai 2010), one of which is community activities in Islamic boarding schools. Cooperatives in pesantren are aimed at developing the community's economy in pesantren (Diahastuti 2011). It is hoped that through the activities of the pesantren cooperative, various new businesses that are profitable and can improve the community's welfare in the pesantren environment and outside the pesantren environment will be formed. However, in its development in general, the development of pesantren cooperatives is identical to "small is beautiful," meaning that the business activities of the Islamic boarding school tend to be minor, not developing, running as is to meet the institutional needs of the community in the pesantren (Santosa 2004).

Economica: Jurnal Ekonomi Islam - Volume 11, Nomor 2 (2020)

https://journal.walisongo.ac.id/index.php/economica 
Pesantren cooperatives have great potential to develop due to several reasons are: there are 220 Islamic boarding schools in North Sumatra and 8 Islamic boarding schools in Medan City; Pesantren relates to the conditions of social life and religious traditions of the community around the pesantren area (Zuhirsyan 2018); Islamic boarding schools exist and are fully active within 24 hours; pesantren conducts regeneration to the community environment; Islamic boarding schools are present and gain high trust from the community, and Islamic boarding schools are known to be able to form human resource cadres with popular, modern, and religious characters (Nadzir 2015).

This makes the presence of cooperatives in the pesantren environment very strategic, as a guide for conducting muamalah in the economy in a polite, trustworthy manner, constantly referring to sharia provisions in normative economics by developing activities full of religiosity, full of social life, and beneficial economic muamalah (Gunawan, Pulungan, and Koto 2019)

The development of cooperatives at Islamic boarding schools in Medan City, the center of government activities in North Sumatra, can be an initial reference to the success of its management. It is hoped that a pesantren cooperative that excels in its control and operation is expected to impact the welfare of the community around the pesantren and members of the pesantren cooperative. Through cooperatives, pesantren will be present and grow economic centers with a small and medium scope, from the pesantren environment so that eventually it will have a broad impact on the outside economy, including villages, districts to the city of Medan, North Sumatra, and Indonesia where the pesantren is located. So that in the future it will be a contribution of pesantren in economic activity for the nation.

Based on the background of the issue discussed previously, it is known that pesantren cooperatives have great potential to develop a sharia-based community economy in Islamic boarding schools (Syarbani 2012). However, this potential has not been fully utilized, considering that cooperatives in Islamic boarding schools tend to be minor, undeveloped, and only meet the 
institution's needs. This situation makes one of the factors of pesantren life that they tend not to be independent in managing funds and empowering the community so that the life of the pesantren looks poor and deprived. This problem is necessary to map the issues faced by Islamic boarding schools in the city of Medan..

\section{Literature review}

Pesantren is a place available for students to receive Islamic religious lessons and a gathering place and place to live (A. L. Fikri, Yasin, and Jupri 2018). Islamic boarding school education aims to create and develop a Muslim personality, namely a personality who believes and fears God, has a noble character and is beneficial to society (Effendy 1986).

Kepontren, as a form of sharia in their operations, always ensure that the principles are sharia, without usury, without maisir, without gharar, and without contracts with fraudulent activities (Diahastuti 2011). According to Ahmad Ifham Sholihin (2017), sharia cooperatives in general play a role in maximizing the potential of members' abilities to the fullest for the welfare of members and the socio-economic community. In addition, it also plays a role in seeking the formation of quality resources from cooperative members so that they are always and trustworthy, professional (fathonah), always consistent (istiqomah) in the application of sharia provisions in economic muamalah. Furthermore, Sharia cooperatives also play a role in seeking the realization of a democratic national economy in a familial and polite manner, as an intermediary between the owners of sources of funds and users of funds to achieve distribution and maximization in asset management. As well as strengthening cooperative members to work together optimally, jointly realizing the formation of expansion of employment opportunities, and developing various productive businesses of members.

Sharia Cooperative Foundation (Sholihin 2017) Based on a sense of kinship, referring to the Qur'an, al-Hadith, helping each other (ta'awun), and 
mutually reinforcing among members (takaful). However, its management is still subject to the provisions of the regulation of the State Minister of Cooperatives and Small and Medium Enterprises 194/Per/M.KUKM/VIII/2006.

Cooperatives have funds from their capital to carry out their activities, including principal savings, mandatory savings, and reserve funds. In addition, the source of cooperative loan capital comes from members, prospective members of other cooperatives, banks, and Islamic financial institutions.

Based on the source of these funds, the cooperative conducts business management in consumer, producer, service, and savings and loan cooperatives. Furthermore, cooperative activities are carried out according to sharia, prioritizing what is lawful, reasonable, and beneficial, prioritizing a profit-sharing system without usury, gratuities, vanity, and tadlis (Sholihin 2017).

Referring to the Law of the Republic of Indonesia No. 17 of 2012 concerning cooperatives, that types of cooperatives can be in the form of primary cooperatives or secondary cooperatives. Primary Cooperatives are cooperatives established by and consisting of people, while Secondary Cooperatives are appointed by and composed of legal entities. Savings and Loans Cooperative is a cooperative that runs a savings and loan business as the only business. The savings and loan unit is one of the savings and loan cooperative business units carried out conventionally or sharia. Primary Cooperatives are established by at least 20 (twenty) individuals by separating part of the assets of the founders or members as the initial capital of the cooperative. Secondary Cooperatives are established by at least 3 (three) Primary Cooperatives. Consumer cooperatives carry out service business activities in the field of supplying goods for members and non-members; (2) Producer cooperatives carry out service business activities in the field of procurement of production facilities and marketing of production produced by Members to Members and non-Members; (3) Service cooperatives carry 
out non-savings and loan service business activities required by members and non-members; (4) The Savings and Loans Cooperative runs a savings and loan business as the only business serving members.

A cooperative is considered successful if it can improve its members' welfare and create added value from the efforts of members with the active role and participation of its members. This condition can only be achieved if the cooperative has a good performance. The form of the ability of cooperatives in the welfare of members is measured through one of them is the income of cooperative members. This form of payment can be in the form of money or goods or what consumers can buy. For example, in producer cooperatives, members running a business require cooperative services to provide production inputs, provide credit, and or market the products produced. The purpose of the producer cooperative is to advance the business of its members by increasing the profits to be obtained.

According to Hasyim, the number of Islamic boarding schools that have established cooperatives is still very small (1\%), there are still a small number of pesantren community members who are members of Islamic boarding schools cooperatives (Kepontren), the role and members of Kepontren are still not optimal (medium), there are still a small number of Kepontrens that have not been observed (Aji 2011). The success of its business development is also still low; the motivation for cooperatives in the Kepontren community is based on the culture in the pesantren so that in general, it results in most of the cooperatives in the pesantren (Syarbani 2012).

In its development since 2000, the pesantren cooperative has tried to innovate as a center for people's economic development with their respective characteristics, such as the Sidogiri Islamic boarding school. This condition shows the actual fast adaptation for pesantren to the needs of the times. Even today, at Islamic boarding schools in various parts of Indonesia, several micro waqf banks have grown and developed. However, for North Sumatra, there is only one micro waqf bank, namely a micro waqf bank from Mawariddussalam. 
In its development since 2000, the pesantren cooperative has tried to innovate as a center for people's economic development with their respective characteristics, such as the Sidogiri Islamic boarding school. This condition shows the actual fast adaptation for pesantren to the needs of the times. Especially in the industrial revolution 4.0, where innovation towards digitalization also significantly influences economic progress and growth. Social crowdfunding has changed the way people collect funds from donors to realize new ideas (Fuadi, Farida, and Saadah 2020). Even today, at Islamic boarding schools in various parts of Indonesia, several micro waqf banks have grown and developed. However, for North Sumatra, there is only one micro waqf bank, namely a micro waqf bank from Mawariddussalam Islamic boarding school. This is because pesantren as an educational institution is also a social and economic institution for the community's welfare. One of how the people's interest can be realized is through waqf because waqf is a financial instrument of Islamic development (Fuadi 2018).

The Islamic boarding school indeed has a person in scientific development and socialization of sharia economics to the community and as a place for practice in sharia economics. The scholars in Islamic boarding schools can be role models in muamalah according to Islamic sharia. They can be supervisors in various Islamic financial institutions, playing a role in the sharia function and disseminating sharia economics to the community. As a place for economic actualization, pesantren is the right institution for the younger generation to run their economy. The success of santri as pious, intelligent, and smart entrepreneurs in managing business and muamalah in sharia will be a role model for economic activities outside the pesantren, all of which can be realized by the contribution of sharia cooperatives in Islamic boarding schools, which is carried out optimally as well. It is great to hope for the Islamic economy in Indonesia if all Islamic boarding schools and their cooperatives grow healthy and prosper their members to the maximum. 
The program to optimize the pesantren economy through this cooperative can be realized through various stages: Improving human resources for management and accounting records for cooperatives. This can be done by involving external parties from pesantren cooperatives; it can be through campus educational institutions, training institutions, nongovernmental organizations, Islamic banking, INKOPONTREN, and PINBUK to improve economic management professionally according to Islamic sharia. So far, it seems that pesantren cooperatives are not managed well, tend to be unprofessional, and are only modest, building a good network like networking for access to various parties who can make a real contribution to Islamic boarding school cooperatives as well as building Islamic boarding schools in the future through economic activities that have a multiplier effect on an ongoing basis.

According to Edi Suharto, Social mapping describes the condition of the community that occurs systematically and involves collecting data and information related to the community by listing the profile and social issues that exist in the community (Trisela and Pristiana 2021). Referring to Netting, Kettner, and McMurtry (1993), social mapping can also be referred to as social profiling or "profile making of a community."

Social mapping was carried out in this study in the form of identification of Islamic boarding schools from an internal perspective, namely: in terms of Islamic Boarding School Assets, Islamic School Human Resources, Number of Islamic Boarding School Members, Total Funds managed by the Islamic Boarding School, Islamic Education Business Activities, Supporting Facilities for Islamic Schools, Islamic Education Work Programs, Location of Islamic Schools, and understanding of the operational activities of Islamic boarding school. 


\section{Methods}

The method used in this research is the descriptive qualitative research method. The descriptive analysis deals with questions about independent variables, either only on one or more variables, and does not make comparisons or look for relationships between one variable and another (Sigit 2003).

According to Sugiyono (2008), the qualitative research method is based on the philosophy of post positivism, used to examine the condition of natural objects (as opposed to experimentation). Thus, the researcher is the key instrument, the sampling of data sources is carried out purposively and snowball, the collection technique is triangulation (combined), data analysis is inductive/qualitative, and qualitative research results emphasize meaning rather than generalization.

Literature studies are used more in this study to describe the problem. This research uses a qualitative approach because it interprets, highlights, and explains a unique phenomenon. This research is challenging to measure by quantitative research because it is related to understanding people's experiences related to the wonders. Moleong (2001) says, qualitative research as follows: Qualitative research is research that intends to understand the phenomenon of what is experienced by research subjects such as behavior, perception, motivation, action, and others, holistically by describing in the form of words and language, in particular, natural contexts by utilizing various natural methods.

This study uses one technique of taking informants, namely the purposive sampling technique. Purposive sampling is a technique of getting informants by determining the subject/object according to the purpose. Subjects/objects as the unit of analysis were selected using the personal researcher's considerations according to the research topic. The unit of analysis is chosen according to the needs and considers that the unit of 
analysis is representative. The researcher uses purposive sampling in taking informants because the researchers have their considerations: the informants feel and have experience managing pesantren cooperatives. In this study, samples were used which informants were from 8 Islamic boarding schools in Medan City. Interviews were conducted as primary data sources and to obtain qualitative data types. The data obtained through interviews were then triangulated to ensure the validity of the data obtained.

\section{Result and discussion}

The city of Medan is the 3rd largest metropolitan city in Indonesia after the city of Surabaya. Medan City has an area of $265.1 \mathrm{~km}^{2}$ with a population of $2,229,408$ people. The people of the town of Medan are very heterogeneous, but the majority are residents of the Islamic religion. Currently, the city of Medan has eight Islamic boarding schools consisting of: Ar Raudhatul Hasanah, Islamic boarding school, Al Manar, Islamic boarding school, Ta'dib As Syakirin, Islamic boarding school, Al Kautsar Al Akbar, Islamic boarding school, Yayasan Azzidin, Islamic boarding school, Darul Hikmah TPI Medan, Islamic boarding school, Usman Syarif, Islamic boarding school, and Puteri Aisyah, Islamic boarding school.

As an educational institution that provides a 24-hour integrated education pattern in Islamic boarding schools, Islamic boarding schools usually have cooperatives to help provide various facilities for boarding for students and teachers, and the boarding community. However, in observations made at the 8 Islamic boarding schools cooperatives in Medan City, information was obtained that the cooperative operating system was not all sharia-compliant. In general, it is known that 5 out of $8(62 \%)$ of these cooperatives use a conventional management system.

Only three have used the sharia system (38\%). In general, all pesantren cooperatives in Medan City are all business cooperatives, which carry out savings and loan activities and business management in the form of santri 
Figure 1. Identification of kepontren issue

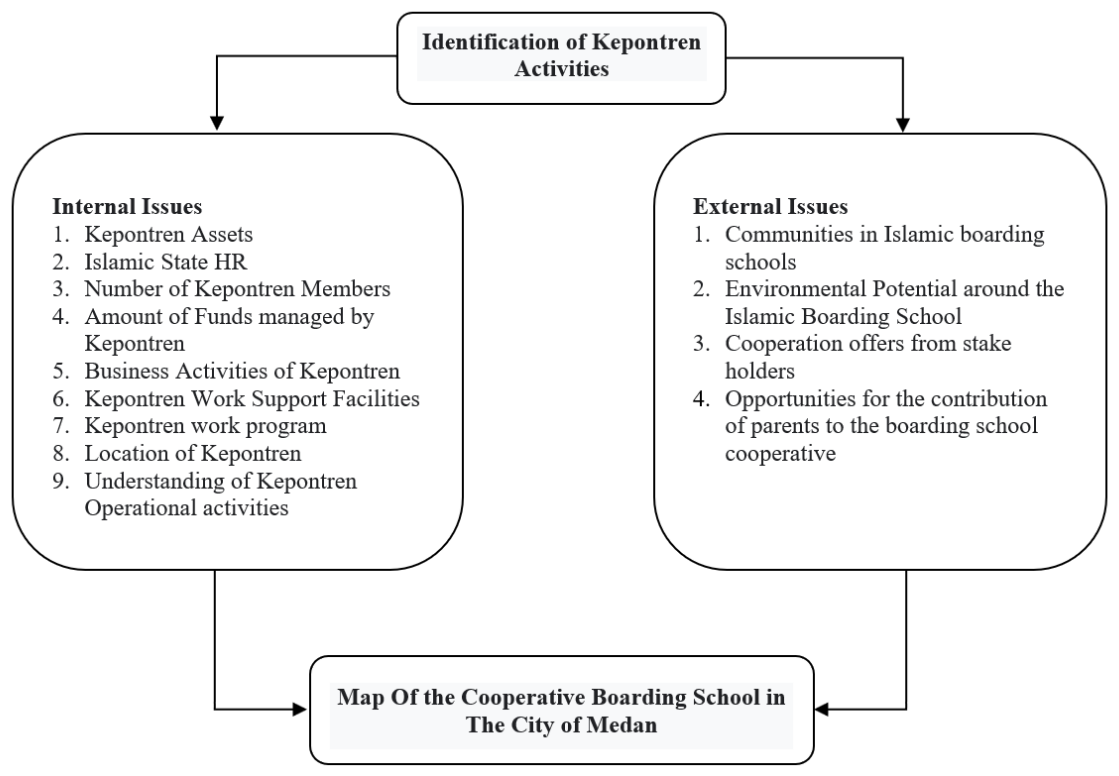

shops or known as santri marts. In the initial observation stage, it is generally known that the issue faced by Islamic boarding school cooperatives include issues faced by internal sources and issues originating from external cooperatives. As illustrated in the figure 1.

Through the picture, it can be seen that from the internal aspect, the capital and assets of the cooperative are one of the factors that determine the issue that arise in the development of the pesantren business. If the cooperative is a savings and loan cooperative, the existence of capital to provide loans to members is one element that can improve the welfare of cooperative members. This ideal condition will be achieved if loans are given to members for business capital activities. Still, if they are for consumptive purposes, it will not affect the welfare of members. This is in line with the research findings by Dewi Ambarwati (Ambarwati et al. 2017). 
Another internal factor that is considered to have the potential to hinder the development of a boarding school business is the limited knowledge of Human Resources, incredibly cooperative management (Marsudi, Arief, and Zahrok 2011). Cooperative management in its business management is the main element determining the success of cooperatives. The innovation and strategy of Islamic boarding school cooperatives in the economic empowerment of students is essential by improving and improving institutional management, membership, management, finance, partnerships, and business unit development (Sujianto 2009). The success of the pesantren cooperative will enhance the welfare of the pesantren, santri, and the community around the pesantren (Chusmeru 2018). This is in line with the research results conducted by Chusmeru (2017), so that investment in cooperative human resource assets, especially management, is important (Burhanuddin 2016; Kasanudin 2011).

To analyze whether this general phenomenon also occurs in pesantren cooperatives in Medan City, interviews were conducted with several heads of Islamic boarding schools in Medan City. In carrying out the activity to obtain information from the leaders of each of the Kepontren, the researchers visited the 5 Kepontrens. Still, the data was only obtained from 3 cooperatives: Chairman of the Al Manar Islamic Boarding School Cooperative, Head of the Ta'dib As Syakirin Islamic Boarding School Cooperative, and Chairman of the Al Kautsar Islamic Boarding School Cooperative. Al Akbar, Chairman of the Azzidin Foundation Boarding School and Chairman of the Darul Hikmah Islamic Boarding School Cooperative TPI Medan, Medan City.

\section{Condition of the AL Manar islamic boarding school cooperative}

Ustad leads the AL Manar Islamic Boarding School Cooperative. Nasirrudin, M.Ag. Currently, the cooperative has 22 teachers and serves approximately 200 students. The cooperative does not yet have an official business license; therefore, in managing its activities, it only carries out 
activities to serve children buying snacks and school necessities such as stationery. Based on Mrs. Mardiah as the custodian of the Al Manar Islamic Boarding School, it is known that every day the cooperative serves Mts students only during school hours. On holidays, it is closed, so that it is closed cooperative service hours are not 24 hours. From its daily operational activities, the cooperative can earn up to s.d. IDR 300,000,-. The funds are replayed for activities the next day. Based on the interview with Mr. Nasirrudin, it is known that currently, for the management and storage of funds for teachers and students who wish, the pesantren cooperates with BMT Kampoeng Syariah, which has an office close to the location of the Al Manar Islamic Boarding School.

Taking into account the internal issue commonly faced by Islamic boarding school cooperatives, it is known that the Al Manar Islamic Boarding School Cooperative has issues: the Kepontren's assets are not recorded, the quality of the Islamic boarding school's human resources is minimal, and their knowledge is not upgraded, the number of members of the Islamic boarding school is minimal and tends to be internal only, the amount of funds managed by the Islamic boarding school is still low turnover per day 200-300 thousand, Islamic boarding school business activities are limited to consumptive activities only with internal boarding school consumers, very minimal working support facilities for Islamic boarding schools, there are no Islamic education work programs, the location of Islamic boarding schools is very strategic, and understanding of the operational activities of Islamic boarding schools is low. While the issue that come from external to the pesantren are the lack of community involvement in the pesantren environment, the potential of the environment around the pesantren which is potential to be utilized for the pesantren business but is not utilized, the opportunities for collaboration from stakeholders have not been utilized, nor have the opportunities for the contribution of parents to the pesantren cooperative been exploited. 
Figure 2. Mapping the issue of the al manar islamic boarding school cooperative
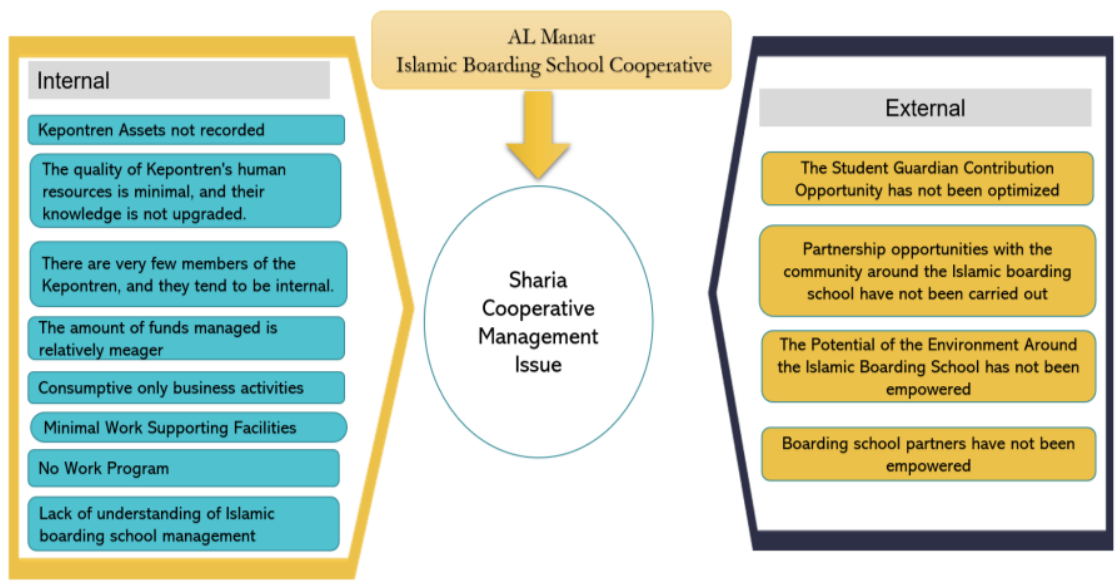

\section{Condition of the ta'dib as syakirin islamic boarding school cooperative}

$T a^{\prime} d i b$ As Syakirin Cooperative is a type of consumption cooperative, which serves shop activities for the needs of students. The cooperative is chaired by Mrs. Fatimah, S.PdI, and assisted by Mrs. Retno Miranti as her representative. Based on the results of interviews conducted with Mrs. Ranti, it is known that the number of cooperative participants is currently 20 teachers and 170 students. Cooperative management is still done traditionally by recording in the ledger. Borrowing activities are also provided for participants but students with grades up to s.d. tens of thousands only. Members of teachers and clerics and ustadjah are allowed to borrow up to hundreds of thousands. However, the nature of the loan is concise; that is, it must be repaid 1 to 1 s.d. 6 months. This is due to the limited data owned by the cooperative. Management of canteen activities is paid Rp. 300,000/month divided by three people. So that every month per shopkeeper gets Rp. $100,000,-$.

Economica: Jurnal Ekonomi Islam - Volume 11, Nomor 2 (2020) 
Figure 3. Mapping the issue of the Ta'dib As Syakirin islamic boarding school cooperative
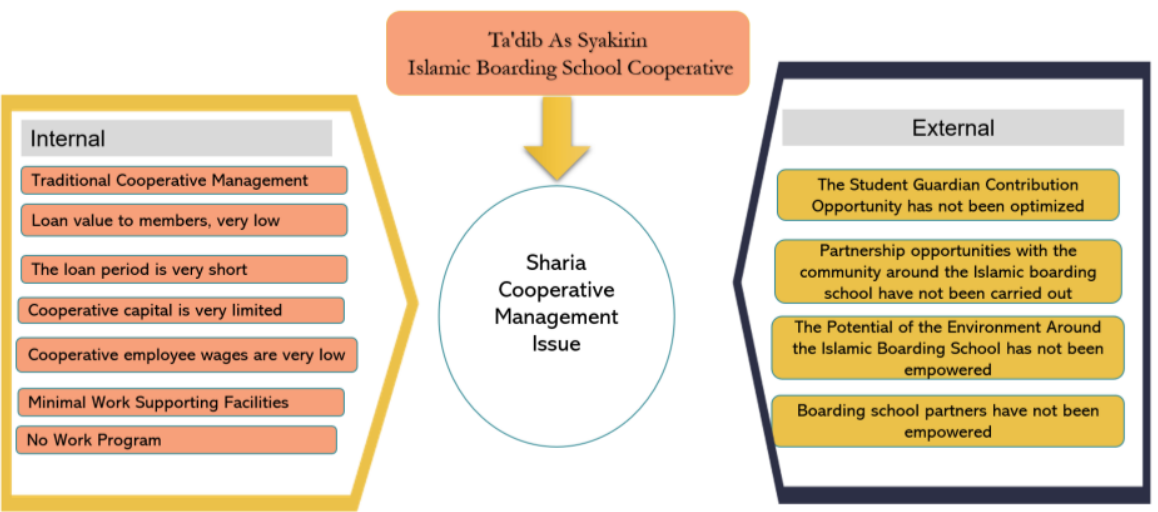

\section{Condition of the Darul Hikmah islamic boarding school TPI Medan}

The Darul Hikmah TPI Medan Islamic boarding school cooperative belongs to the category of pesantren with good management. Eli Juliati, S.Ag., Secretary Indra Syahputra, and Mrs. Umroh as treasurers, this cooperative is chaired. This cooperative has 60 teachers as participants. Santri are only intended as customers or consumers of the cooperative. The cooperative that is managed includes the cooperative for wasteful activities. The businesses owned by the cooperative include the business of managing shops and canteens. The store manager of the cooperative is carried out every year with different administrators; the authority is given to each teacher, in turn, every year. Every period, a general meeting is held regularly for all cooperative members, which is every March. The distribution of the remaining profits of the cooperative is given to all members with a value ranging from Rp. 100,000 to Rp. IDR 1,000,000. This value depends on the contribution of each member and the period the member joins the cooperative.

The management has established cooperation with several Islamic banks, specifically with the Mandiri Syariah Bank and the Syariah State Savings Bank. The Darul Hikmah cooperation with the Sharia State Savings 
Bank is also realized by mobile cash cars every Wednesday. The presence of the mobile cash car is realized by the number of students as well as teachers and the community around the pesantren who save or withdraw cash on the mobile cash car. The location of the boarding school cooperative is in the building close to the canteen so that people outside the boarding school cannot access it; it is only intended for the pesantren community.

The business activities of the Islamic boarding school are limited to consumptive activities with internal consumers of Islamic boarding schools, the means of supporting the work of the Islamic boarding school are very minimal, the work program of the Islamic boarding school does not exist. Therefore, while the issue that comes from external to the pesantren is the lack of community involvement in the Islamic boarding school environment, the potential of the environment around the boarding school which is potential to be utilized for the pesantren business but is not utilized the opportunities for collaboration from stakeholders have not been utilized, nor have the opportunities for the contribution of parents to the pesantren cooperative been utilized.

Figure 4. Mapping the issue of the Darul Hikmah islamic boarding school
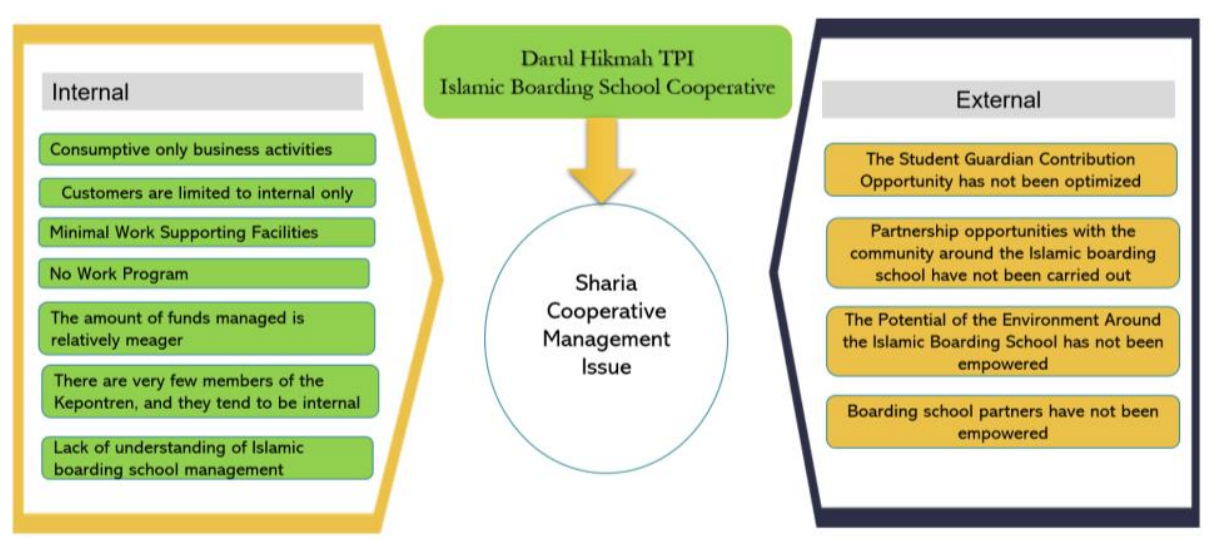

Economica: Jurnal Ekonomi Islam - Volume 11, Nomor 2 (2020) https://journal.walisongo.ac.id/index.php/economica 


\section{Conclusion}

The issue faced by the Islamic Boarding School Cooperative in Medan City consists of internal issues and external issues. The internal issues of the Islamic Boarding School Cooperative are the unregistered assets of the Islamic boarding school, the minimal quality of the Islamic boarding school's human resources, the knowledge that is not improved, and the number of members of the Islamic boarding school is minimal. In addition, the amount of funds managed by Islamic boarding schools is still low, and the business activities of Islamic boarding schools are limited to consumptive activities. In addition, Islamic boarding school internal consumers, supporting facilities for Islamic boarding schoolwork are minimal, Islamic boarding school work programs do not exist, the location of Islamic boarding schools is mostly very strategic, and understanding of Islamic boarding school operational activities is low.

Meanwhile, the external issues of the pesantren are the lack of community involvement in the pesantren environment, the non-optimization of the potential of the surrounding environment, the untapped opportunities for stakeholder collaboration, and the untapped contribution opportunities of parents.

Mapping the condition of Islamic Boarding School Cooperatives in Medan City, it can be seen that of the eight registered Cooperatives in Medan City, only 3 Islamic Boarding School cooperatives (37.5\%) are active and quite good and are pretty prosperous for their members, while the remaining $62.5 \%$ of Islamic Boarding School cooperatives are not yet developed. Tend to be minor, modest, and only exist to sell the needs of Islamic boarding school students. Most pesantren cooperatives tend not to carry out any activities and strategies to solve their cooperative issue. This is due to the impression that the cooperative management itself does not consider the operation of the joint to be a problem but a regular and sufficient thing because there are still profits that can be rotated every day even though it is only around 10-20. 
Mapping of Sharia Cooperative Management Issue in ...

\section{References}

Aji, Gunawan. 2011. "Faktor-Faktor Yang Mempengaruhi Kinerja Koperasi Pondok Pesantren." Walisongo: Jurnal Penelitian Sosial Keagamaan 19 (1): 231. https://doi.org/10.21580/ws.19.1.219.

Ambarwati, Dewi, Muhammad Mudjib Musta'in, Supriyadi Supriyadi, and Sayekti Suindyah Dwiningwarni. 2017. "Pengaruh Penyaluran Dana Koperasi Terhadap Kesejahteraan Ekonomi Anggota Kepontren Sunan Bonang Pondok Pesantren Parengan-Tuban." Journal of Public Power 1 (1): 57-66. https://doi.org/10.32492/jpp.v1i1.187.

Burhanuddin, B. 2016. "Evaluasi Program Pendidikan Dan Latihan Pada Koperasi Pondok Pesantren." ECONOMIC:Jurnal Ekonomi Dan Hukum Islam 6 (1): 1-9.

Chusmeru, C. 2018. "Revitalisasi Dan Model Pengkaderan Dalam Pengembangan Koperasi Pesantren." Prosiding 8 (1).

Chusmeru, C, M Masrukin, and S Pangestuti. 2017. "Koperasi Pondok Pesantren Sebagai Pemberdayaan Ekonomi Santri." Prosiding.

Diahastuti, R. 2011. "Peranan Koperasi Dalam Meningkatkan Kesejahteraan Masyarakat Di Sekitar Pondok Pesantren Assalaam." Universitas Negeri Semarang.

Effendy, M. 1986. Membangun Koperasi Di Madrasah Dan Pondok Pesantren. Jakarta: Bhratara Karya Aksara.

Fikri, Ahmad Lutfi Rijalul, Muaidy Yasin, and Akhmad Jupri. 2018. "Konsep Pengelolaan Koperasi Pesantren Untuk Kesejahteraan Ekonomi Masyarakat: Telaah Surah Al-Hasyr Ayat 7." ISLAMICONOMIC: Jurnal Ekonomi Islam 9 (2): 131-50. https://doi.org/10.32678/ijei.v9i2.96.

Fikri, Ahmad Lutfi, Muaidy Yasin, and Akhmad Jupri. 2018. "Telaah Surah AlHasyr Ayat 7: Konsep Pengelolaan Koperasi Pesantren Untuk Kesejahteraan Ekonomi Masyarakat." Jurnal Ilmiah Ekonomi Islam 4 (2): 103-15. https://doi.org/10.29040/jiei.v4i02.249.

Fuadi, Nasrul Fahmi Zaki. 2018. "Wakaf Sebagai Instrumen Ekonomi Pembangunan Islam." Economica: Jurnal Ekonomi Islam 9 (1): 151. https://doi.org/10.21580/economica.2018.9.1.2711.

Fuadi, Nasrul Fahmi Zaki, Dessy Farida, and Naili Saadah. 2020. "Empathy or Self-Credibility? An Empirical Study of Intentions to Donate through

Economica: Jurnal Ekonomi Islam - Volume 11, Nomor 2 (2020) 
Social Crowdfunding Using the UTAUT Model." In Proceedings of the Proceedings of the 1st Conference on Islamic Finance and Technology, CIFET, 21 September, Sidoarjo, East Java, Indonesia. EAI. https://doi.org/10.4108/eai.21-9-2019.2293953.

Gunawan, A, D R Pulungan, and M Koto. 2019. Tingkat Literasi Keuangan Dosen Fakultas Ekonomi Dan Bisnis Universitas Muhammadiyah Sumatera Utara. Prosiding Seminar Bisnis Magister ....

Kasanudin, M. 2011. Pengaruh Kualitas Sumber Daya Manusia (SDM) Pengelola Koperasi Terhadap Kinerja Koperasi Pondok Pesantren Di Kabupaten Demak. eprints.walisongo.ac.id.

Marsudi, Marsudi, Usman Arief, and Siti Zahrok. 2011. "Pengembangan Manajemen Koperasi Di Pondok Pesantren Perguruan Islam Salafiah Kabupaten Blitar." Jurnal Sosial Humaniora 4 (2). https://doi.org/10.12962/j24433527.v4i2.631.

Moleong, L. J. 2001. Metode Penelitian Kualitatif. Remaja Rosdakarya.

Nadzir, Mohammad. 2015. "Membangun Pemberdayaan Ekonomi Di Pesantren." Economica: Jurnal Ekonomi Islam 6 (1): 37-56. https://doi.org/10.21580/economica.2015.6.1.785.

Sakai, Minako. 2010. “Growing Together in Partnership:Women's Views of the Business Practices of an Islamic Savings and Credit Cooperative (Baitul Maal Wat Tamwil) in Central Java, Indonesia." Women's Studies International Forum $33 \quad$ (4): $412-21$. https://doi.org/10.1016/j.wsif.2010.02.015.

Santosa, Purbayu Budi. 2004. "Eksistensi Koperasi: Peluang Dan Tantangan Di Era Pasar Global. Jurnal Dinamika Pembangunan." Jurnal Dinamika Pembangunan 1 (2).

Sholihin, Ahmad Ifham. 2017. Buku Pintar Ekonomi Syariah. Jakarta: Gramedia Pustaka Utama.

Sigit, Santoso. 2003. Pengantar Metodologi Penelitian Sosial Bisnis Manajemen. Yogyakarta: Fakultas Ekonomi UST.

Soemitra, Andri. 2017. Bank Dan Lembaga Keuangan Syariah. Jakarta: Prenada Media Group.

Sugiyono. 2008. Metode Penelitian Kuantitatif Kualitatif Dan $R$ Dan $D$. Bandung: Alfabeta. 
Sujianto, A E. 2009. "Pengaruh Pembinaan Anggota, Modernitas Kyai, Kinerja Pengurus Dan Partisipasi Anggota Terhadap Kinerja Koperasi Pondok Pesantren Di Kabupaten Tulungagung." SKRIPSI Mahasiswa UM.

Syarbani, Hasyim. 2012. "Analisis Pengaruh Partisipasi Santri Komitmen Dan Kemampuan Berinovasi Terhadap Kinerja Koperasi Pondok Pesantren Di Kota Semarang." Economica: Jurnal Ekonomi Islam 2 (2): 27-42. https://doi.org/10.21580/economica.2012.2.2.848.

Trisela, Intan Pramudita, and Ulfi Pristiana. 2021. "Analisis Perbandingan Kinerja Keuangan Bank Syariah Dengan Bank Konvensional Yang Terdaftar Di Bursa Efek Indonesia Periode 2014 - 2018." JEM17: Jurnal Ekonomi Manajemen 5 (2). https://doi.org/10.30996/jem17.v5i2.4610.

Wasiaturrahma, Shochrul Rohmatul Ajija, Raditya Sukmana, Tita Novita Sari, and Ahmad Hudaifah. 2020. "Breadth and Depth Outreach of Islamic Cooperatives: Do Size, Non-Performing Finance, and Grant Matter?" Heliyon 6 (7): e04472. https://doi.org/10.1016/j.heliyon.2020.e04472.

Zuhirsyan, Muhammad. 2018. "Membidik Potensi Ekonomi Syariah Di Lembaga Pendidikan Pondok Pesantren." Economica: Jurnal Ekonomi Islam 9

(2): 319-47. https://doi.org/10.21580/economica.2018.9.2.2781. 
Marlya Fatira AK 